\title{
Physical and Mechanical Properties of Clear Wood from Red Oak and White Oak
}

\author{
Marly G. Carmona Uzcategui, R. Daniel Seale, and Frederico José Nistal França * \\ Red oak and white oak are common names of species that grow in the \\ eastern United States with great economic importance. This study aimed \\ to evaluate the visual, physical, and mechanical properties of small clear \\ wood specimens of red oak (Quercus spp.) and white oak (Quercus spp.). \\ The experiments were carried out on defect-free specimens extracted \\ from boards supplied by the Stairbuilders Manufacturers Association \\ (SMA) members. The material was obtained from sawmills located in the \\ eastern half of the United States. A total of 181 boards (90 boards of red \\ oak and 91 boards of white oak) were submitted for tests. Compression \\ strength was found to be higher than the values published in past studies. \\ Red oak exhibited higher MOE and MOR values compared to white oak. \\ The mechanical properties for red oak and white oak have not changed \\ substantially because the average values remain in a range that is very \\ close to the values published in the past 100 years. Thus, the values from \\ the Wood Handbook can still be used for engineering purposes.
}

Keywords: Modulus of elasticity; Modulus of rupture; Compression parallel; Compression perpendicular; Janka hardness

Contact information: Department of Sustainable Bioproducts, Mississippi State University, P.O. Box 9820, Starkville, MS 39759 USA; *Corresponding author: fn90@ msstate.edu

\section{INTRODUCTION}

Oak (Quercus spp.) is a genus composed of a diverse group of tree species that have been reported as one of the most widely used hardwoods in Europe and North America (Merela and Čufar 2013). In the United States, red oak grows naturally in eastern and central states, while white oak distribution includes the South, South Atlantic, and Central States (Kretschmann 2010). Red oak and white oak have been identified as species of great economic interest for the stair and guard construction, thus the characterization of their mechanical properties is required for wooden structural applications. Past investigations have demonstrated that both red oak and white oak wood are hard, strong in bending, and endwise compression (Brown et al. 1949). These characteristics makes them suitable as structural materials; however, currently these species do not have assigned allowable design properties to engineer structural applications that comply with the building codes and standards (Bendtsen and Ethington 1975; Cooper 2014).

Oaks are ring-porous hardwoods with high density in the latewood part of the growth ring. Because the changes in the ring width of oaks has been more associated with change in width of latewood, the percentage of latewood increase alongside ring width. Generally, this allows the wood density of oak as well as other strength properties to increase as growth rate increases. However, the density of some trees may decline with further increase in width ring generated from a very fast growth rate (Nepveu 1993). Variations in latewood density can be associated with variation in the latewood structure as well as changes in the proportions between earlywood and latewood (Rao et al. 1997). 
Red oak and white oak have great aesthetic qualities that make them appealing for different uses such as furniture, striking tool handles, baseball bats, bowling pins, stairways and interior paneling, general millwork, cabinets, highway guardrail posts, pallets among others. Both are also widely used for flooring because of their hardness and other characteristics that make them ideal for this purpose. Other uses for white oak and red oak include railroad ties, fence posts, poles, and mine timbers. (Brown et al. 1949).

Currently, the staircase industry in U.S is seeking to develop the design values for domestic hardwood commonly used in stairways with the expectation to increase their use in domestic wood construction. Testing to verify the physical and mechanical properties is necessary to compare the wood used today with information obtained from studies conducted nearly 100 years ago (Newlin and Wilson 1917; Markward and Wilson 1935). Although physical and mechanical properties of oak are known, there is an uncertainty with respect to the average values. For this reason, performing mechanical tests to evaluate possible changes in their properties is important to maintain current information that meets regulations and building codes.

Despite the variation that can be found in wood due to the influence of several factors such as climate, the region of growth, the wood anatomy, silviculture, and manufacture practices, the Staircase Manufacturers Association (SMA) made efforts to provide oak wooden boards of the highest quality used by SMA members to manufacture staircases. This study will provide useful information to perform future calculations or adjustments in published design values for staircases. In this sense, the purpose of this study was to evaluate physical and mechanical properties of red oak and white oak to supplement available information on these species. Specific objectives were: i) to determine the growth rings counting (GRC) and percentage of latewood (\%LW); ii) to test physical properties (moisture content (MC) and specific gravity (SG)); iii) to test mechanical properties of small clear wood specimens (static bending, compression parallel and perpendicular to the grain, and Janka hardness; and iv) to compare the results from both species with the published values in earlier studies.

\section{EXPERIMENTAL}

\section{Materials and Sample Preparation}

The origin of the material came from Northeast, Upper Midwest, Southeast MidSouth, Appalachian, and southeastern region and the boards were donated by staircase manufacturers. The boards were kiln dried, defect free, and straight grained. These characteristics are generally required by stairway manufacturers. Boards were kept in a controlled environment $\left(21^{\circ} \mathrm{C}\right.$ and $65 \%$ relative humidity $\left.(\mathrm{RH})\right)$ for several weeks before initial testing.

Prior to the physical and mechanical tests, each board was labeled with the initial of the species name and a unique number, to organize the boards per species and facilitated the data collection. The boards were originally 1 -inch thick $(2.54 \mathrm{~cm}), 1.9$ inches $(4.8 \mathrm{~cm})$ width, and 37.8 inches $(96 \mathrm{~cm})$ in length. Rings per inch (RPI), percent of latewood (LW), manufacture location, moisture content (MC), and temperature were collected from 90 red oak and 91 white oak boards. Width, length, thickness, and weight were recorded to calculate the density of each board.

Growth rings counting (GRC) was calculated by counting the number of the rings and dividing by the thickness or the width depending on the grain orientation of the piece 
(radial or tangential). Percentage of latewood (LW) was determined using a 1 by 1 in. (2.54 by $2.54 \mathrm{~cm}$ ) dot grid. The LW was estimated by dividing the number of dots that fell on LW by the total number of dots in the grid. Both measurement techniques followed Southern Pine Inspection Bureau (SPIB) standard grading rules (SPIB 2014). Board density was determined using the bulk weight and the bulk volume. The $\mathrm{SG}_{12} \%$ followed the specifications of ASTM 2395 (ASTM 2017) standard. Moisture content was determined using a moisture meter from Wagner, model MMC 220.

After initial measurements, each board was cut into physical and mechanical properties specimens in accordance with the "secondary method" of specimen preparation explained in Section 8.1 of ASTM-D 143 (2014). The secondary method was selected by default because the boards were 1-inch thick.

From each board, one specific gravity, two for static bending (radial and tangential), two compression (one parallel and one perpendicular), and one Janka hardness specimens were cut following the scheme in Figure 1.

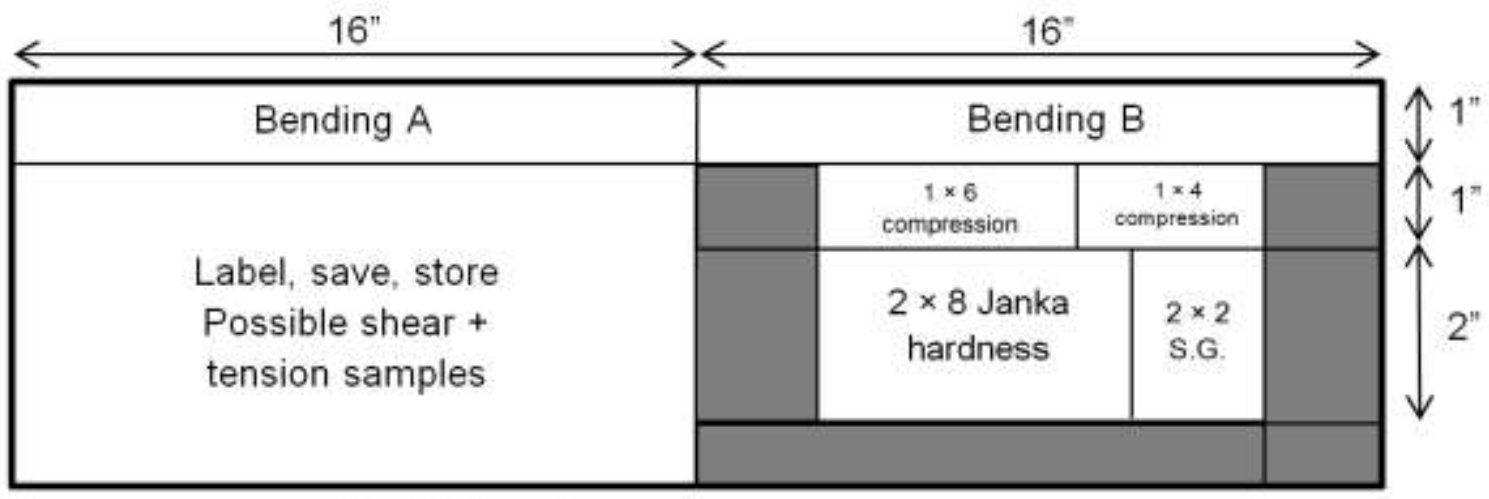

$\square$-Discard

Fig. 1. Cutting scheme of small clear wood specimens from the boards.

\section{Testing Procedures}

Tests of specific gravity, static bending, compression parallel and perpendicular to grain, and Janka hardness were conducted. Each specimen was weighed and measured before testing. The mechanical tests were performed using Instron universal testing machines with the Bluehill 3 software (Instron, Norwood, MA, USA) to control operations. The generated data were recorded directly into a Structured Query Language (SQL) database to minimize typing errors.

\section{Specific gravity}

The SG specimen's sizes were $1 \times 2 \times 2$ inches $(2.54 \times 5.08 \times 5.08 \mathrm{~cm})$. The dimensions of each specimen were collected, and then the specimens were oven dried (103 $\pm 2{ }^{\circ} \mathrm{C}$ ). Oven dried weight of the specimens were recorded after the mass was stabilized.

\section{Static bending test}

Static bending specimens were $1 \times 1 \times 16$ inches $(2.54 \times 2.54 \times 40.64 \mathrm{~cm})$. The load span was 14 inches $(35.6 \mathrm{~cm})$. The test was conducted using center point loading with a test speed of 0.05 inches $(0.127 \mathrm{~cm})$ per minute (Fig. 2A). Tests were done in radial and tangential directions (Fig. 2B). For radial specimens, load was applied on one of the radial 
faces. For tangential specimens, load was applied on the face nearest to the pith. The failure type was recorded for each specimen. Modulus of elasticity was calculated using Eq. 1,

$$
M O E=\frac{\Delta \cdot P \cdot L^{3}}{4 \cdot \Delta \cdot f \cdot b \cdot h^{3}}
$$

where $M O E$ is the bending modulus of elasticity (MPa), $\triangle P$ is the loading increase $(\mathrm{N}), L$ is the span length (m), $\Delta f$ is the deflection increase $(\mathrm{m}), b$ is the width $(\mathrm{m})$, and $h$ is the depth of the specimen $(\mathrm{m})$. Likewise, the modulus of rupture was calculated using Eq. 2,

$$
M O R=\frac{3 \cdot P \cdot L}{2 \cdot b \cdot h^{2}}
$$

where $M O R$ is the bending modulus of rupture $(\mathrm{MPa}), P$ is the maximum force $(\mathrm{N})$ at the mid-span, $L$ is the span length (m), $b$ is the width $(\mathrm{m})$, and $h$ is the depth (m).

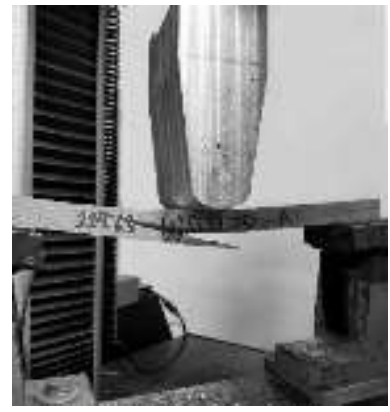

A

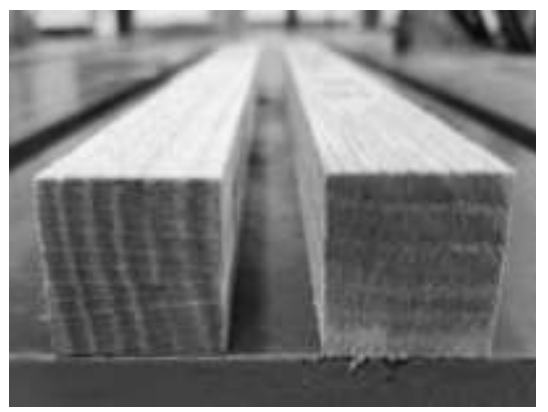

B

Fig. 2. A) Static Bending test setup. B) Bending tests were done in radial and tangential direction.

Compression parallel to grain

Test specimens measured $1 \times 1 \times 4$ inches $(2.54 \times 2.54 \times 10.16 \mathrm{~cm})$. The load was applied at a rate of $0.003 \mathrm{in} / \mathrm{in}(0.00762 \mathrm{~cm} / \mathrm{cm})$ of nominal specimen length $/ \mathrm{min}$. The type of deformation was recorded for each specimen. Figure 3-A exhibits the testing setup.

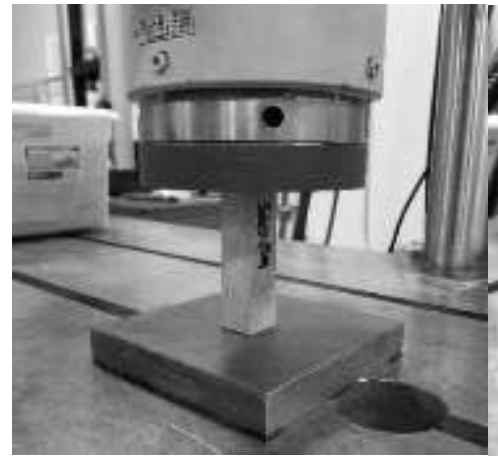

A

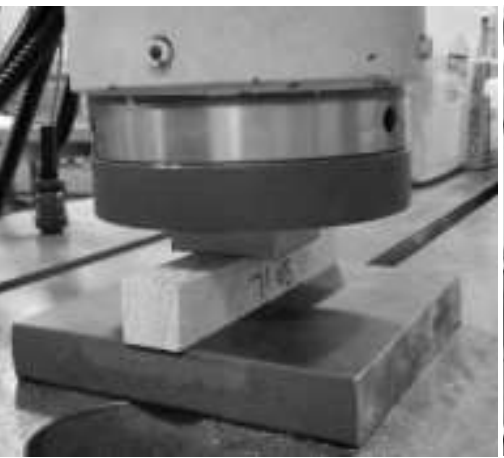

B

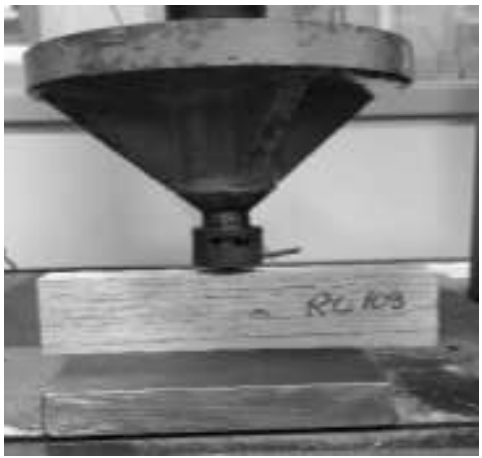

C

Fig. 3. A) Compression parallel to the grain; B) Compression perpendicular to the grain; C) Janka ball side hardness

Compression perpendicular to grain

Each specimen measured $1 \times 1 \times 6$ in $(2.54 \times 2.54 \times 15.24 \mathrm{~cm})$. The load was applied through a bearing plate 2 inches $(5.08 \mathrm{~cm})$ wide, placed at the top of the specimen 
to be in contact with its radial surface (Fig. 3-B). The speed rate of loading was 0.012 inches $(0.305 \mathrm{~mm})$ per minute.

\section{Janka hardness}

The tests were performed on $1 \times 2 \times 6$ inch $\left(2.54 \times 5.08 \times 15.24 \mathrm{~cm}^{3}\right)$ specimens. During the test, a 0.444 -inch $(1.13 \mathrm{~cm})$ ball was embedded to half its diameter into each specimen at a rate of $0.25 \mathrm{in} / \mathrm{min}(0.6 \mathrm{~cm} / \mathrm{min})$. Two penetrations were made on each specimen in their radial surface and two penetrations on the tangential surface. The speed of testing was 0.25 inches $(6 \mathrm{~mm})$ per minute, as indicated in the standard (Fig. 3-C).

\section{RESULTS AND DISCUSSION}

A summary of the growth characteristics and physical properties of red oak and white oak specimens is given in Table 1. The average moisture content of the red oak boards varied between 4.7 and $15.6 \%$ with a mean value of $11.0 \%$ and a coefficient of variation of $19.96 \%$. Moisture content of white oak boards varied between 8.0 to $17.1 \%$ with an average value of $12.5 \%$ and a coefficient of variation of $19.34 \%$. Growth rings counting for red oak varied between 1.1 and 18.5 with a mean of 7.3 and a coefficient of variation of $48.52 \%$. For white oak, growth rings counting varied between 1.3 and 23.9 with a mean of 9.6 and a coefficient of variation of $46.22 \%$.

Table 1. Moisture Content, Rings per Inch, Percentage of Latewood, Board Density, and Specific Gravity values, for Red Oak and White Oak

\begin{tabular}{|c|c|c|c|c|c|c|c|}
\hline Species & $\mathbf{N}$ & Properties & Mean & Min & Max & SD & CV (\%) \\
\hline \multirow{5}{*}{ Red Oak } & \multirow{5}{*}{90} & M.C (\%) & 11.0 & 4.7 & 15.6 & 2.2 & 19.96 \\
\hline & & GRC & 7.3 & 1.1 & 18.5 & 3.53 & 48.52 \\
\hline & & \% Latewood & 71.3 & 42.2 & 98.4 & 12.96 & 18.17 \\
\hline & & Board Density $\left(\mathrm{kg} \cdot \mathrm{m}^{-3}\right)$ & 699 & 571 & 853 & 57.99 & 8.31 \\
\hline & & $\mathrm{SG}_{12 \%}$ & 0.65 & 0.54 & 0.77 & 0.05 & 8.33 \\
\hline \multirow{5}{*}{$\begin{array}{c}\text { White } \\
\text { Oak }\end{array}$} & \multirow{5}{*}{91} & M.C (\%) & 12.5 & 8.0 & 17.1 & 2.41 & 19.34 \\
\hline & & GRC & 9.6 & 1.3 & 23.9 & 4.41 & 46.22 \\
\hline & & \% Latewood & 67.8 & 35.9 & 96.9 & 14.69 & 21.66 \\
\hline & & Board Density $\left(\mathrm{kg} \cdot \mathrm{m}^{-3}\right)$ & 756 & 599 & 887 & 67.44 & 8.91 \\
\hline & & $\mathrm{SG}_{12 \%}$ & 0.71 & 0.55 & 0.83 & 0.06 & 9.00 \\
\hline
\end{tabular}

The average percentage of latewood of the red oak varied between 42.2 and 98.4 with a mean value of 71.3 and a coefficient of variation of $18.17 \%$. Percentage of latewood of white oak varied between 35.9 and 96.9 with a mean of 67.8 and a coefficient of variation of $21.66 \%$. Density for red oak varied between 571 and 853 with a mean of 699 and a coefficient of variation of $8.31 \%$. For white oak, the density varied between 599 and 887 with a mean of 756 and a coefficient of variation of $8.91 \%$. The mean specific gravity of the red oak was found to be 0.65 , with a coefficient of variation of $8.33 \%$ and 0.54 and 0.77 as minimum and maximum average values, respectively. For white oak, the SG mean was found to be 0.71 , with a minimum of 0.55 and a maximum of 0.83 and a coefficient of variation of $9.0 \%$.

Static bending modulus of elasticity (MOE) and modulus of rupture (MOR) values, in radial and tangential directions, for red oak and white oak are listed in Table 2. For red oak in radial direction, the MOE values ranged from 7,070 to $17,500 \mathrm{MPa}$, with a mean 
value of $12,000 \mathrm{MPa}$ and a coefficient of variation of $16.33 \%$. In tangential direction, MOE values ranged between 8,160 and $18,100 \mathrm{MPa}$, with a mean value of $12,400 \mathrm{MPa}$ and a coefficient of variation of $14.82 \%$. The average MOE for red oak varied between 7,070 and $18,100 \mathrm{MPa}$ with a mean of $12,200 \mathrm{MPa}$ and a coefficient of variation of $15.61 \%$.

Table 2. Static Bending Modulus of Elasticity (MOE) and Modulus of Rupture (MOR) values, in radial and tangential directions, for Red Oak and White Oak

\begin{tabular}{|c|c|c|c|c|c|c|c|}
\hline \multirow{2}{*}{ Species } & \multirow{2}{*}{$\mathbf{N}$} & \multicolumn{6}{|c|}{ Static Bending (MPa) } \\
\hline & & Direction & Variable & Mean & Min & Max & CV (\%) \\
\hline \multirow{6}{*}{ Red Oak } & \multirow{2}{*}{90} & \multirow{2}{*}{ Radial } & MOE & 12,024 & 7,074 & 17,533 & 16.33 \\
\hline & & & MOR & 118 & 65 & 170 & 19.67 \\
\hline & \multirow{2}{*}{89} & \multirow{2}{*}{ Tangential } & MOE & 12,404 & 8,157 & 18,133 & 14.82 \\
\hline & & & MOR & 122 & 73 & 162 & 17.24 \\
\hline & \multirow[b]{2}{*}{179} & \multirow[b]{2}{*}{ Average } & MOE & 12,211 & 7,074 & 18,133 & 15.61 \\
\hline & & & MOR & 120 & 65 & 170 & 18.49 \\
\hline \multirow{6}{*}{$\begin{array}{c}\text { White } \\
\text { Oak }\end{array}$} & \multirow{2}{*}{91} & \multirow{2}{*}{ Radial } & MOE & 11,273 & 6,667 & 15,961 & 17.89 \\
\hline & & & MOR & 112 & 59 & 153 & 20.13 \\
\hline & \multirow{2}{*}{91} & \multirow{2}{*}{ Tangential } & MOE & 11,328 & 7,915 & 15,879 & 16.48 \\
\hline & & & MOR & 115 & 62 & 157 & 17.50 \\
\hline & \multirow{2}{*}{182} & \multirow{2}{*}{ Average } & MOE & 11,300 & 6,667 & 15,961 & 17.15 \\
\hline & & & MOR & 113 & 59 & 157 & 18.82 \\
\hline
\end{tabular}

For white oak, MOE values in radial direction ranged from 6,670 to $16,000 \mathrm{MPa}$, with a mean value of $11,300 \mathrm{MPa}$ and coefficient of variation of $17.89 \%$. In tangential direction, MOE values ranged between 7,920 and 15,900 MPa, with a mean value of 11,300 $\mathrm{MPa}$ and coefficient of variation of $16.48 \%$. The average MOE for white oak varied between 6,670 and $16,000 \mathrm{MPa}$ with a mean of $11,300 \mathrm{MPa}$ and coefficient of variation of $17.15 \%$.

The mean MOR, for red oak, in radial and tangential were $118 \mathrm{MPa}$ and $122 \mathrm{MPa}$, respectively. In radial direction, the minimum, maximum, and coefficient of variation values were $65 \mathrm{MPa}, 170 \mathrm{MPa}$, and $19.67 \%$, respectively. In tangential direction, the minimum, maximum, and coefficient of variation values were $73 \mathrm{MPa}, 162 \mathrm{MPa}$, and $17.24 \%$, respectively. The average MOR for red oak varied between 65 and 170 with a mean of $120 \mathrm{MPa}$ and coefficient of variation of $18.49 \%$.

For white oak, the mean MOR in radial and tangential were $112 \mathrm{MPa}$ and $115 \mathrm{MPa}$, respectively. In radial direction, the minimum, maximum, and coefficient of variation values were $59 \mathrm{MPa}, 153 \mathrm{MPa}$, and $20.13 \%$, respectively. In the tangential direction, the minimum, maximum, and coefficient of variation values were $62 \mathrm{MPa}, 157 \mathrm{MPa}$, and $17.50 \%$, respectively. The average MOR for white oak varied between 59 and 157 with a mean of $113 \mathrm{MPa}$ and a coefficient of variation of $18.82 \%$.

Compression parallel and compression perpendicular results for red oak and white oak are listed in Table 3. For red oak, compression parallel values ranged from 47 to 80 $\mathrm{MPa}$, with a mean value of $61 \mathrm{MPa}$ and coefficient of variation of $11.47 \%$. For white oak, compression parallel values ranged from 42 to $75 \mathrm{MPa}$, with a mean value of $60 \mathrm{MPa}$ and coefficient of variation of $12.90 \%$. For compression perpendicular, red oak values ranged from 11 to $33 \mathrm{MPa}$, with a mean value of $18 \mathrm{MPa}$ and coefficient of variation of $20.84 \%$. 
For white oak, compression perpendicular values ranged from 11 to $26 \mathrm{MPa}$, with a mean value of $18 \mathrm{MPa}$ and coefficient of variation of $17.33 \%$.

Table 3. Compression Parallel and Perpendicular values, for Red Oak and White Oak

\begin{tabular}{|c|c|c|c|c|c|c|}
\hline \multirow{2}{*}{ Species } & \multirow{2}{*}{ Direction } & \multicolumn{5}{|c|}{ Compression (MPa) } \\
\cline { 3 - 7 } & & N & Mean & Min & Max & CV (\%) \\
\hline \multirow{2}{*}{ Red Oak } & Parallel & 81 & 61 & 47 & 80 & 11.47 \\
\cline { 2 - 7 } & Perpendicular & 90 & 18 & 11 & 33 & 20.84 \\
\hline \multirow{2}{*}{ White Oak } & Parallel & 91 & 60 & 42 & 75 & 12.90 \\
\cline { 2 - 7 } & Perpendicular & 91 & 18 & 11 & 26 & 17.33 \\
\hline
\end{tabular}

Janka hardness results for red oak and white oak are listed in Table 4. For red oak, Janka hardness values in the radial direction ranged from 3.9 to $10.2 \mathrm{kN}$, with a mean value of $5.8 \mathrm{kN}$ and coefficient of variation of $19.19 \%$. In the tangential direction, red oak hardness values ranged from 3.8 to $10.5 \mathrm{kN}$ with a mean of $6.3 \mathrm{kN}$ and coefficient of variation of $19.13 \%$. The average hardness for red oak varied between 3.8 and 10.5 with a mean of6.1 kN and coefficient of variation of $19.55 \%$.

For white oak, Janka hardness values in the radial direction ranged from 2.9 to 9.2 $\mathrm{kN}$, with a mean value of $5.9 \mathrm{kN}$ and coefficient of variation of $21.26 \%$. In the tangential direction, white oak values ranged from 4.0 to $10.4 \mathrm{kN}$, with a mean value of $6.6 \mathrm{kN}$ and coefficient of variation of 20.22. The average hardness for white oak varied between 2.9 and 10.4 with a mean of $6.3 \mathrm{kN}$ and coefficient of variation of $21.34 \%$.

Table 4. Janka Hardness values, in radial and tangential directions, for Red Oak and White Oak

\begin{tabular}{|c|c|c|c|c|c|c|}
\hline \multirow{2}{*}{ Species } & \multirow{2}{*}{ Direction } & \multicolumn{5}{|c|}{ Janka Hardness (kN) } \\
\cline { 3 - 7 } & & $\mathbf{N}$ & Mean & Min & Max & CV (\%) \\
\hline \multirow{3}{*}{ Red Oak } & Radial & 179 & 5.8 & 3.9 & 10.2 & 19.19 \\
\cline { 2 - 7 } & Tangential & 181 & 6.3 & 3.8 & 10.5 & 19.13 \\
\cline { 2 - 7 } & Average & 360 & 6.1 & 3.8 & 10.5 & 19.55 \\
\hline \multirow{3}{*}{ White Oak } & Radial & 180 & 5.9 & 2.9 & 9.2 & 21.26 \\
\cline { 2 - 7 } & Tangential & 180 & 6.6 & 4.0 & 10.4 & 20.22 \\
\cline { 2 - 7 } & Average & 180 & 6.3 & 2.9 & 10.4 & 21.34 \\
\hline
\end{tabular}

\section{Comparisons with previous publications}

When comparing these results with the values published by other authors in previous years, it can be seen that the growth rings counting, the percentage of latewood, and the specific gravity slightly varied. The growth rings counting from the current study were found to be lower compared to the literature. In addition, the percentage of latewood was found to be within the range of the values reported by Newlin and Wilson (1917), Markwardt and Wilson (1935), and the Wood Handbook (Kretschmann 2010). Specific gravity, was also found to be within the range of the values reported previously (see Figs. 4 and 5).

Overall, red oak exhibited higher MOE and MOR values compared to white oak. MOE values for red oak were similar to the results obtained by Newlin and Wilson (1917) but slightly higher than the values obtained from Markwardt and Wilson (1935) and the Wood Handbook (Kretschmann 2010). MOR values for red oak were higher than those 
published by Newlin and Wilson (1917) and Markwardt and Wilson (1935) as well as the Wood Handbook (Kretschmann 2010) (See Figs. 6-A and 6-B).

MOE values for white oak were slightly lower than Newlin and Wilson (1917), Markwardt and Wilson (1935), and the Wood Handbook (Kretschmann, 2010) (see Fig. 6A). MOR values for white oak were slightly higher than those published by Newlin and Wilson (1917) and Markwardt and Wilson (1935) as well as the Wood Handbook (Kretschmann 2010).

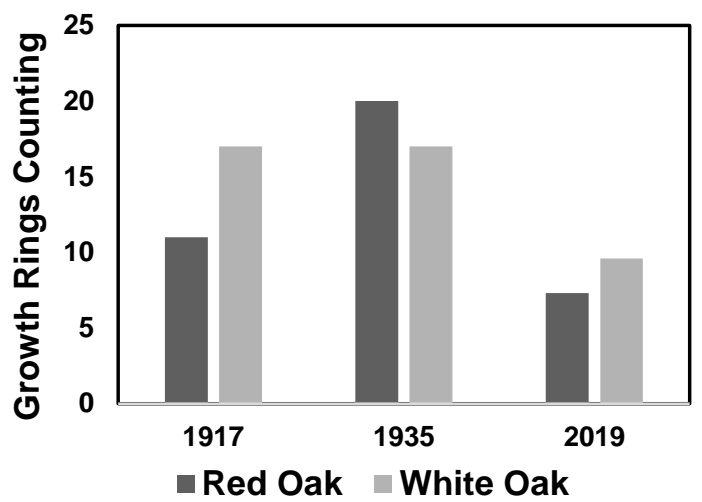

A

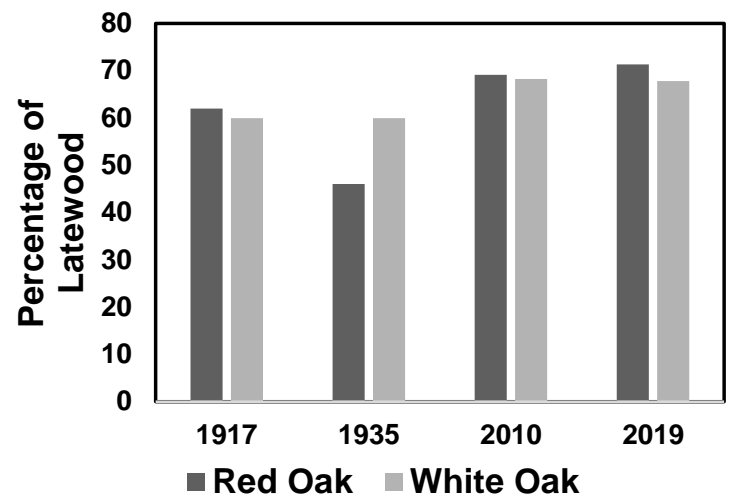

B

Fig. 4. A) Comparison of growth rings counting; B) Comparison of percentage of latewood

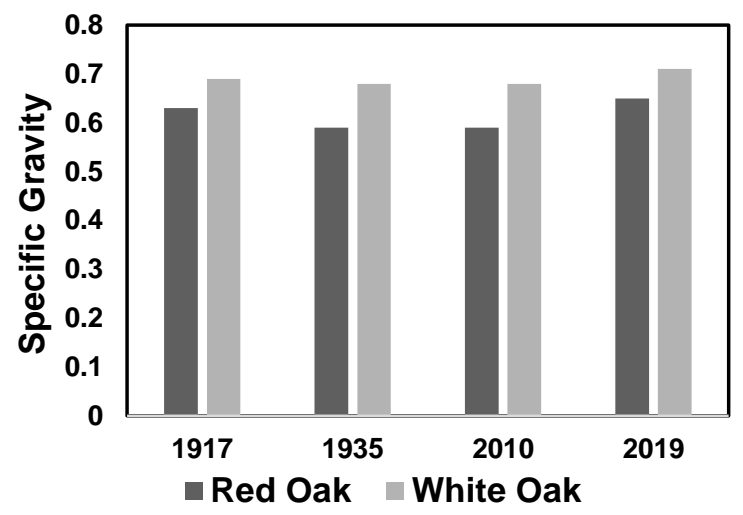

Fig. 5. Comparison of specific gravity

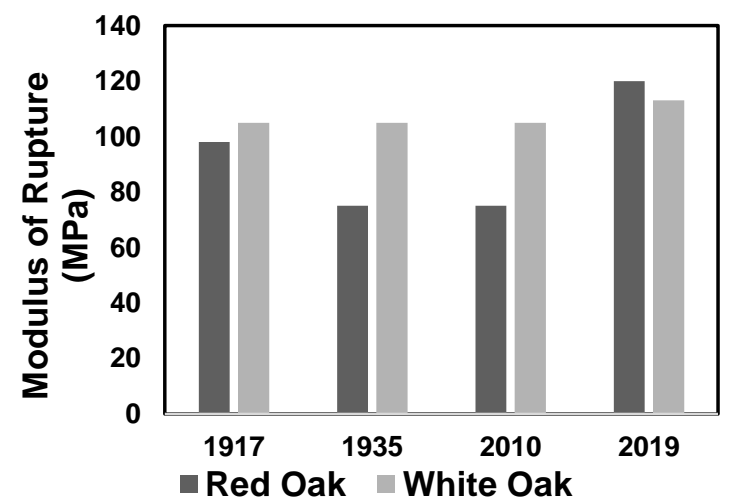

A

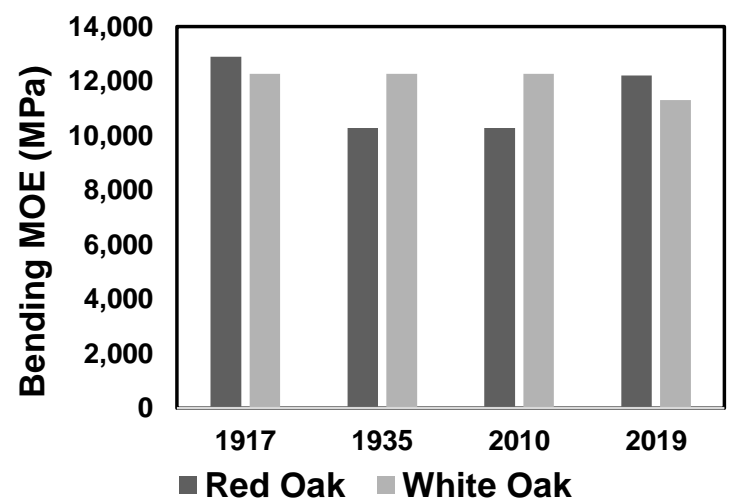

B

Fig. 6. A) Comparison of modulus of rupture; B) Comparison of modulus of elasticity MOE 
Values of compression parallel to the grain, for red oak and white oak, were slightly higher than those published by Newlin and Wilson (1917) and Markwardt and Wilson (1935) as well as the Wood Handbook (Kretschmann 2010). However, for compression perpendicular to the grain, both species showed higher values than the reported for the mentioned authors (See Figs. 7A and 7B).

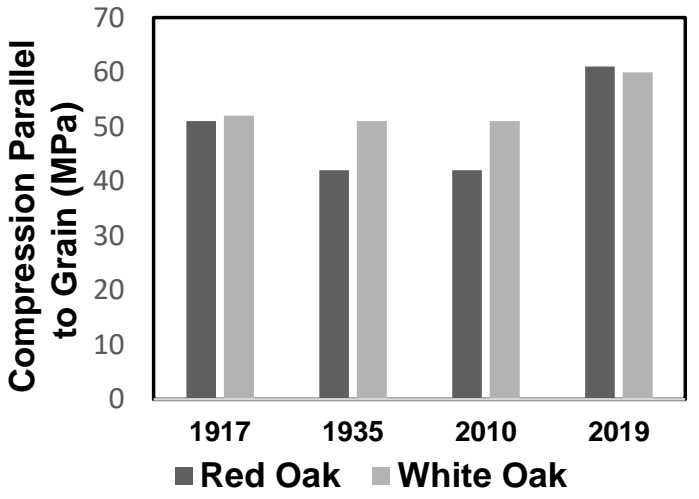

A

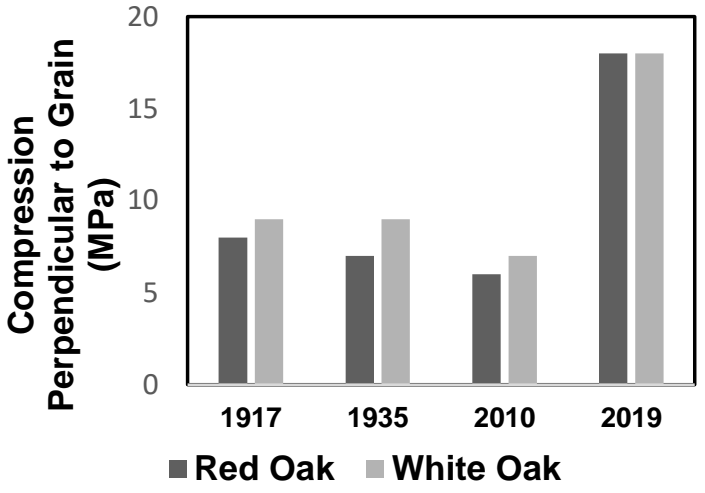

B

Fig. 7. A) Comparison of compression parallel to grain; B) Comparison of compression perpendicular to grain

Values of Janka hardness, for red oak were slightly higher than those reported by Newlin and Wilson (1917) and higher than those reported by Markwardt and Wilson (1935) as well as the Wood Handbook (Kretschmann 2010). White oak hardness values were within the range reported by the mentioned literature. Northwest Hardwoods (2018) recommends the rating of $4.74 \mathrm{kN}$ for red oak and $6.05 \mathrm{kN}$ for white oak as its industry benchmark.

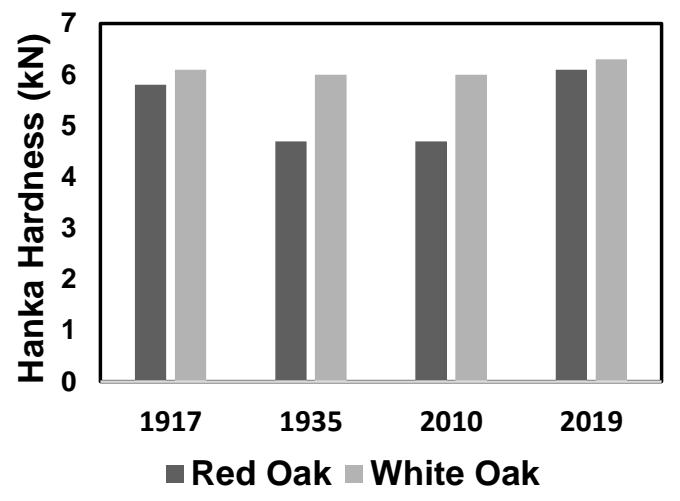

Fig. 8. Comparison of Janka Hardness

\section{Mean Comparisons}

Two-sample $t$ tests were performed to determine whether there were significant mean differences in growth characteristics, physical, and mechanical properties between red oak and white oak, as shown in Table 5. The $t$ test was performed using the average values (radial and tangential of each property). 
Table. 5. Two-sample $t$ test for Growth Characteristics, Physical, and Mechanical Properties

\begin{tabular}{|c|c|c|c|c|c|c|c|}
\hline Test & Species & N. & Mean & SD & $t$ & df & p-value \\
\hline \multirow{2}{*}{ GRC } & Red oak & 178 & 7.27 & 3.62 & \multirow{2}{*}{5.35} & \multirow{2}{*}{352} & \multirow{2}{*}{$<.0001$} \\
\hline & White oak & 176 & 9.55 & 4.21 & & & \\
\hline \multirow{2}{*}{$\begin{array}{l}\text { Percentage of } \\
\text { Latewood (\%) }\end{array}$} & Red oak & 178 & 71.30 & 12.96 & \multirow{2}{*}{2.37} & \multirow{2}{*}{352} & \multirow{2}{*}{0.02} \\
\hline & White oak & 176 & 67.81 & 14.69 & & & \\
\hline \multirow{2}{*}{ Density $\left(\mathbf{k g} \cdot \mathbf{m}^{-3}\right)$} & Red oak & 89 & 699 & 57.99 & \multirow{2}{*}{6.04} & \multirow{2}{*}{175} & \multirow{2}{*}{$<.0001$} \\
\hline & White oak & 88 & 755 & 67.44 & & & \\
\hline \multirow{2}{*}{ Specific Gravity } & Red oak & 90 & 0.65 & 0.05 & \multirow{2}{*}{6.14} & \multirow{2}{*}{175} & \multirow{2}{*}{$<.0001$} \\
\hline & White oak & 87 & 0.71 & 0.06 & & & \\
\hline \multirow{2}{*}{ Bending MOE (MPa) } & Red oak & 179 & 12,211 & 1907 & \multirow{2}{*}{4.50} & \multirow{2}{*}{359} & \multirow{2}{*}{$<.0001$} \\
\hline & White oak & 182 & 11,300 & 1939 & & & \\
\hline \multirow{2}{*}{ Bending MOR (MPa) } & Red oak & 179 & 120 & 22.2 & \multirow{2}{*}{2.88} & \multirow{2}{*}{359} & \multirow{2}{*}{0.004} \\
\hline & White oak & 182 & 113 & 21.4 & & & \\
\hline \multirow{2}{*}{$\begin{array}{c}\text { Compression Parallel } \\
(\mathrm{MPa})\end{array}$} & Red oak & 81 & 61 & 7.0 & \multirow{2}{*}{6.14} & \multirow{2}{*}{175} & \multirow{2}{*}{$<.0001$} \\
\hline & White oak & 91 & 60 & 7.7 & & & \\
\hline \multirow{2}{*}{$\begin{array}{c}\text { Compression } \\
\text { Perpendicular (MPa) }\end{array}$} & Red oak & 90 & 18 & 3.9 & \multirow{2}{*}{0.01} & \multirow{2}{*}{179} & \multirow{2}{*}{0.98} \\
\hline & White oak & 91 & 18 & 3.2 & & & \\
\hline \multirow{2}{*}{ Janka Hardness (kN) } & Red oak & 360 & 6.1 & 1.1 & \multirow{2}{*}{2.32} & \multirow{2}{*}{707} & \multirow{2}{*}{0.02} \\
\hline & White oak & 360 & 6.3 & 1.3 & & & \\
\hline
\end{tabular}

$\alpha=0.05,2$-tailed

For growth rings counting, the mean GRC values for red oak and white oak small clear specimens were 7.27 and 9.55, respectively. A two-sample $t$ test revealed significant difference between the two means at the 0.05 level $(\mathrm{p}<.0001)$. For percentage of latewood, the mean value for red oak was 71.30, while the mean for white oak was 67.81. A two sample $t$ test between these means revealed a significant difference between the red oak and white oak percentage of latewood $(p=0.02)$.

The mean SG values for red oak and white oak small clear specimens were 0.65 and 0.71 , respectively. A two-sample $t$-test revealed a significant difference between the two means for specific gravity at the 0.05 level $(p=<.0001)$. The mean density value for red oak was 699 while the mean density for white oak was 755. A two sample $t$ test revealed a significant difference between the two means density at the .05 level $(p=<.0001)$.

As shown in Table 5, the mean MOE values for the red oak and white oak small clear specimens were $12,211 \mathrm{MPa}$ and $11,300 \mathrm{MPa}$, respectively. A two-sample $t$ test revealed a significant difference between the two means at the .05 level $(p=<.0001)$. The corresponding mean MOR values of $120 \mathrm{MPa}$ and $113 \mathrm{MPa}$ for red oak and white oak, respectively, are shown in Table 5. The $t$ test for MOR comparison revealed a significant difference $(p=0.004)$.

For compression parallel and perpendicular to the grain, the mean for red oak was $61 \mathrm{MPa}$ and $18 \mathrm{MPa}$ respectively. For white oak, the mean in compression parallel and perpendicular to the grain was $60 \mathrm{MPa}$ and $18 \mathrm{MPa}$ respectively. A two sample $t$-test revealed a significant difference between the two means $(p=<.0001)$ for compression parallel to the grain, and no significant difference between the two means for compression perpendicular to the grain $(p=0.98)$. The mean Janka hardness values for red oak and white oak were $6.1 \mathrm{kN}$ and $6.3 \mathrm{kN}$ respectively. A two-sample $t$ test revealed a significant difference between the two means for hardness at the 0.05 level $(p=0.02)$. 


\section{CONCLUSIONS}

1. The mechanical properties for red oak and white oak have not changed substantially, as shown by the finding that the average values remain in a range that is very close to those published in the past 100 years. The values from the Wood Handbook thus can still be used for engineering purposes.

2. Modulus of elasticity (MOE) and modulus of rupture (MOR) values from the present study were similar to those from past studies.

3. Growth rings counting for both species decreased when compared with past studies.

4. Compression perpendicular to the grain was found to be higher than the values published in past studies.

5. Overall, red oak exhibited higher MOE and MOR values compared to white oak. In general, the evaluated mechanical properties values of red oak are significantly different from the white oak.

\section{ACKNOWLEDGMENTS}

This research was funded by a grant from the USDA Forest Service. This publication is a contribution and approved as journal article SB 969 of the Forest and Wildlife Research Center (FWRC), Mississippi State University and it was. The authors are also thankful for technical assistance provided by Franklin Quin and Edward Entsminger, to carry out the above work.

\section{REFERENCES CITED}

ASTM International (2009). ASTM D143-09: "Standard test methods for small clear specimens of timber," West Conshohocken, PA.

ASTM International (2017). "Standard test methods for small clear specimens of timber. ASTM D 2395," ASTM International, West Conshohocken, PA, USA

Bendtsen, B. A., and Ethington, R. L. (1975). "Mechanical properties of 23 species of eastern hardwoods," USDA Forest Service, Forest Products Laboratory Res, Madison, WI Note FPL-0230, pp. 12

Brown, H. P., Panshin, A. J., and Forsaith, C. C. (1949). Textbook of Wood Technology, McGraw-Hill Book Company Inc., New York, NY, USA.

Cooper, D. S. M. (2014). "The demand for structural appearance-grade hardwoods," National Hardwood Magazine, 44-45. Retrieved in 08/09/2019 from https://www.stairways.org/Resources/Documents/STRUCTURAL\%20HARDWOOD.pdf

Kretschmann, D. E. (2010). "Mechanical properties of wood," in: Wood Handbook: Wood as an Engineering Material: Centennial Ed., General technical report FPL ; GTR-190. Madison, WI: U.S. Dept. of Agriculture, Forest Service, Forest Products Laboratory, 2010, Chapter 5, pp. 5.1-5.46.

Markwardt. L. J., and Wilson, T. R. C. (1935). "Strength and related properties of woods grown in the United States," USDA Forest Service, Forest Products Laboratory, Technical Bulletin N. 479, Washington, DC. pp. 99. 
Merela, M., and Čufar, K. (2013). "Density and mechanical properties of oak sapwood versus heartwood in three different oak species," Retrieved 07/08/2019, from http://eprints.gozdis.si/582

Northwest Hardwoods (2018). "Hardwood Janka Rating," Retrieved 01/15/2019, from https://northwesthardwoods.com/wp-content/uploads/2018/04/NWH-HardwoodJanka-Ratings-Chart-1.pdf

Nepveu, G. (1993). "The possible status of wood quality in oak breeding programs (Quercus petraea Liebl. and Quercus robur L.)," Ann. Sci. For. 50(Suppl. 1), 388s$394 \mathrm{~s}$.

Newlin, J. A., and Wilson, T. R. C. (1917). "Mechanical properties of woods grown in the United States," USDA Forest Service, Forest Products Laboratory, Technical Bulletin N556, Washington, DC. pp. 551-575.

Rao, R. V., Aebischer, D. P., and Denne, M. P. (1997). "Latewood density in relation to wood fibre diameter, wall thickness, and fibre and vessel percentages in Quercus robur L.," IAWA Journal 18(2), 127-138. DOI: 10.1163/22941932-90001474

Southern Pine Inspection Bureau (SPIB). (2014). "Standard grading rules for southern pine lumber," SPIB, Pensacola, Florida, 147 pp.

Article submitted: January 21, 2020; Peer review completed: April 18, 2020; Revised version received and accepted: May 6, 2020; Published: May 13, 2020.

DOI: 10.15376/biores. 15.3.4960-4971 